\title{
Asymmetric hydrosilylation of ketones catalyzed by complexes formed from trans-diaminocyclohexane-based diamines and diethylzinc
}

\author{
Jadwiga Gajewy $\cdot$ Jacek Gawronski • \\ Marcin Kwit
}

Received: 19 December 2011/Accepted: 12 March 2012/Published online: 18 April 2012

(C) The Author(s) 2012. This article is published with open access at Springerlink.com

\begin{abstract}
Chiral acyclic and macrocyclic amines derived from trans-1,2-diaminocyclohexane in complexes with diethylzinc efficiently catalyze asymmetric hydrosilylation of aryl-alkyl and aryl-aryl ketones with enantiomeric excess of the product up to $86 \%$. A trianglamine ligand with a cyclic structure or the presence of an additional coordinating group increases the enantioselectivity of the reaction, in comparison with catalysis by a simple acyclic $N, N^{\prime}$-dibenzyl-1,2-diaminocyclohexane ligand. In addition, the effect of the asymmetric activation of the catalyst by a variety of alcohols and diols is studied.
\end{abstract}

Keywords Homogeneous catalysis - Metal complexes · Ligands · Macrocycles · Asymmetric activation · Zinc

\section{Introduction}

Secondary alcohols are an important class of chiral building blocks in organic synthesis and form structural fragments of numerous biologically active compounds [1]. Major asymmetric catalytic methods for preparation of secondary alcohols rely mainly either on asymmetric hydrogenation of ketones, with use of chiral rhodium complexes as catalysts in both homogeneous and heterogeneous approaches, or on oxazaborolidine-catalyzed asymmetric reduction of ketones

Electronic supplementary material The online version of this article (doi:10.1007/s00706-012-0754-0) contains supplementary material, which is available to authorized users.

J. Gajewy · J. Gawronski · M. Kwit ( $)$

Department of Chemistry, A. Mickiewicz University,

60-780 Poznan, Poland

e-mail: Marcin.Kwit@amu.edu.pl with diborane [2-6]. Before the re-invention of the reductive properties of polymethylhydrosiloxane (PMHS), a safe and inexpensive by-product of the silicon industry, hydrosilylation of $\mathrm{C}=\mathrm{O}$ bonds seemed a less convenient method because of the toxicity and cost of monomeric silanes. Since the discovery of Zn-diamine-catalyzed asymmetric hydrosilylation of prochiral ketones, several other methods for enantioselective reduction of the $\mathrm{C}=\mathrm{O}$ bonds have been developed [7-23]. They are mainly based on the use of chiral transition metal complexes with P,P-bidentate ligands, $\mathrm{P}, \mathrm{S}$-ligands, $\mathrm{N}$-ligands, or $\mathrm{N}$-heterocyclic carbene ligands. Although the enantioselectivity obtained by use of these complexes is $>90 \%$, use of such complexes suffers from high cost and elaborate preparation. In contrast, use of catalytic systems based on zinc has emerged as a promising and advantageous method for metal-catalyzed asymmetric hydrosilylation of prochiral ketones (Scheme 1).

According to the original procedure developed by Mimoun et al. [7] the reaction requires chiral 1,2-diamine as ligand for dialkylzinc. Modifications could be made either by judicious choice of chiral ligand, by adding an activator, or by changing the reaction conditions (temperature, solvent). The ligands were usually obtained from commercially available amines, for example 1,2-diamino-1,2-diphenylethane or 1-phenylethylamine. However, enantiomerically pure trans-1,2-diaminocyclohexane (DACH) is the preferred source of a virtually unlimited number of diamine structures. Apart from simple acyclic $N, N^{\prime}$-disubstituted derivatives, the ability to make complex structures of triangular, rhombic, or spherical character from suitable substrates is well documented for DACH [24-29]. Another possibility of modifying the structure and properties of macrocyclic DACH derivatives is available by further $\mathrm{N}$-substitution and/or by formation of additional chiral centers at the benzylic positions and introduction of other 


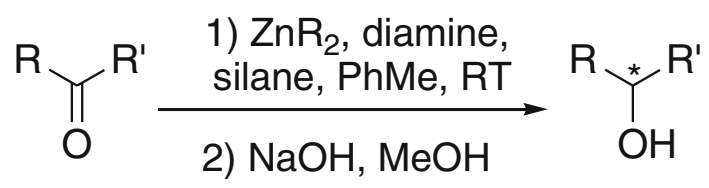

Scheme 1

functional groups in the ligand structure [30, 31]. Chiral macrocyclic tetramine and hexamine macrocycles derived from trans-1,2-diaminocyclohexane in complexes with diethylzinc efficiently catalyze asymmetric hydrosilylation of aryl-alkyl ketones and imines with enantiomeric excess of the product up to $99 \%[32,33]$.

Introduction of two different chiral centers into the ligand structure may give rise to synergistic effects, leading to and increase in the enantioselectivity of hydrosilylation reaction [34]. The basic concept consists in the idea of "asymmetric activation", introduced by Mikami and co-workers and subsequently applied to several enantioselective transformations [35-39]. By following this concept, Ushio and Mikami have developed an efficient method for hydrosilylation of ortho-substituted benzophenones by use of chiral [Zn(diamine)(diol)] complexes, with chirality residing in the diamine part of the complex (Scheme 2) [38]. Prochiral benzophenones can be enantioselectively reduced with up to $96 \%$ ee of the product. The effect of an activator on the stereochemistry of the product was negligible, because enantioselectivity was comparable irrespective of whether $(R)$ or $(S)$-BINOL, or ethylene glycol was used.

Recently Bette et al. [39, 40] reported Zn-promoted direct reduction of a variety of ketones to the corresponding alcohols with PMHS in protic solvents. Although the chemical yields of the reactions were quantitative, moderate enantioselectivity (ee up to $55 \%$ ) was obtained by use of a variety of enantiopure diamine ligands. Another possible means of improving the efficiency of the catalyst system was by changing the reaction conditions from an aprotic to a protic solvent-a rather uncommon situation in organometallic chemistry.
The main objective of this work was to test several acyclic or cyclic ligands derived from enantiomerically pure trans-1,2-diaminocyclohexane, which are secondary or tertiary diamines, imines, or heteraphanes with additional substituents with potential coordinating character (Fig. 1).

According to Mimoun's model and our recent results, coordination of the ketone substrate to the $\mathrm{ZnR}_{2}$-amine complex results in release of an alkane (RH) molecule with the formation of $\mathrm{Zn} \cdots \mathrm{O}$ coordinated species in which one of the nitrogen atoms forms a bond to the carbon atom of the carbonyl group [7, 30]. Complexation of the ketone molecule with $\mathrm{C}-\mathrm{N}$ bond formation is accompanied by significant changes of the conformation of the ligand around the coordination site. Alternatively, hydrosilylation may take place by direct silane attack on the activated carbonyl group without significant change of structure of the complex [30]. Ligands used in this study may act according to the first or second model.

This study was inspired by the work of Ushio and Mikami [38] and Costa et al. [37], who reported that enantiopure [ $\mathrm{Zn}$ (diamine)] species could be activated by either enantiopure BINOL or achiral 1,2 or 1,3-diol ligands to form efficient catalysts for asymmetric hydrosilylation of ketones. We were particularly interested in the application of achiral or chiral diols as activators, because the number of available diols is higher than the number of chiral diamines and because the diamines are usually synthesized from the corresponding diols.

We tested several diols (Fig. 2), either chiral or achiral, in combination with appropriate diamines. For chiral diols both enantiomers and racemic mixtures were used, if available.

The effects of temperature and the structure of the silane were also investigated. As test substrate for the $[\mathrm{Zn}$ (diamine)(diol)]-catalyzed reactions we selected 4-methylacetophenone; the general reaction conditions were as shown in Scheme 1, where $\mathrm{R}=4-\mathrm{MeC}_{6} \mathrm{H}_{4}$ and $\mathrm{R}^{\prime}=\mathrm{Me}$.

\section{Scheme 2}

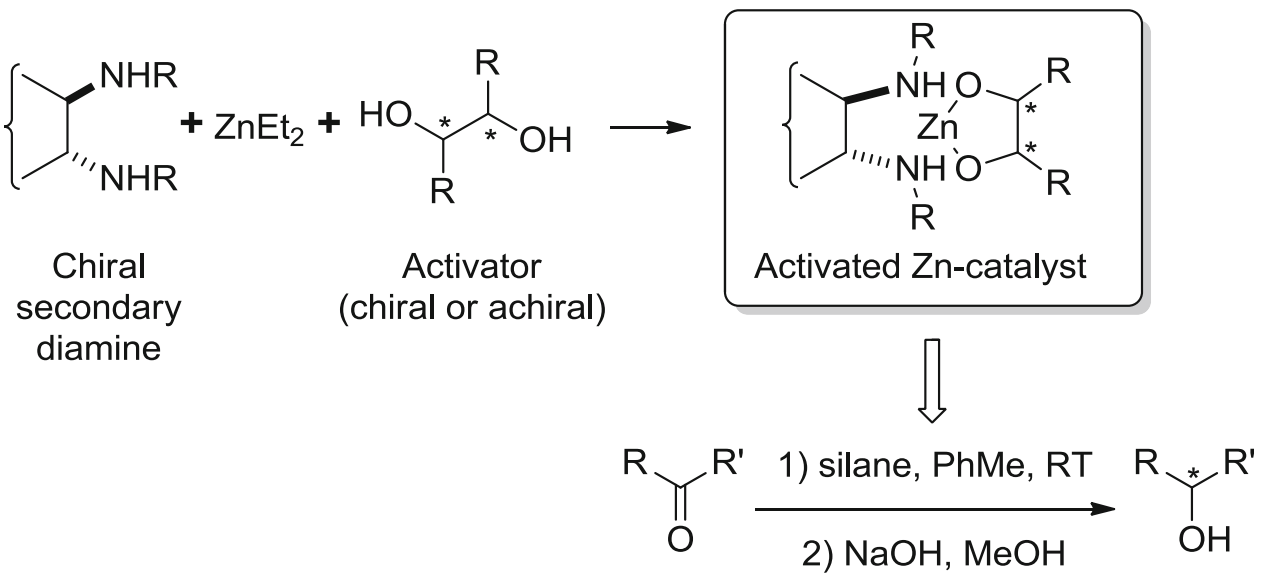


Fig. 1 Acyclic and cyclic ligands used in this study
Fig. 2 Diols and alcohols used as activators in [Zn(diamine)(diol)]-catalyzed hydrosilylations<smiles>[R]CN[C@@H]1CCCC[C@H]1NC[R]</smiles>

L1, $\mathrm{R}=\mathrm{H}$

L2, $\mathrm{R}=\mathrm{Ph}$

L3, $\mathrm{R}=2,4,6-\mathrm{Me}_{3} \mathrm{C}_{6} \mathrm{H}_{2}$

L4, $\mathrm{R}=4-\mathrm{HOC}_{6} \mathrm{H}_{4}$

L5, $\mathrm{R}=4-\mathrm{MeOC}_{6} \mathrm{H}_{4}$

L6, $\mathrm{R}=4-\mathrm{Me}_{2} \mathrm{NC}_{6} \mathrm{H}_{4}$

L7, $\mathrm{R}=2-\mathrm{HOC}_{6} \mathrm{H}_{4}$

L8, $\mathrm{R}=2-\mathrm{MeOC}_{6} \mathrm{H}_{4}$

L9, $\mathrm{R}=2-\mathrm{HO}-3,5-(t-\mathrm{Bu})_{2} \mathrm{C}_{6} \mathrm{H}_{2}$

L11, R = 2-pirydyl
L10, $\mathrm{R}=2-\mathrm{Ph}_{2} \mathrm{PC}_{6} \mathrm{H}_{4}$<smiles>[R2]N[C@@H]1CCCC[C@H]1N[R7]</smiles>

L12, $\mathrm{R}=\mathrm{H}, \mathrm{R}^{\prime}=2,4,6-\mathrm{Me}_{3} \mathrm{C}_{6} \mathrm{H}_{2}$

L13, $\mathrm{R}=\mathrm{Me}, \mathrm{R}^{\prime}=-\mathrm{CH}_{2}-2-\mathrm{HOC}_{6} \mathrm{H}_{4}$

L14, $\mathrm{R}=\mathrm{Me}, \mathrm{R}^{\prime}=-\mathrm{CH}_{2}-\left(2-\mathrm{HO}-3,5-(t-\mathrm{Bu})_{2} \mathrm{C}_{6} \mathrm{H}_{2}\right)$

L15, $\mathrm{R}=\mathrm{H}, \mathrm{R}^{\prime}=-\mathrm{CH}\left(4-\mathrm{BrC}_{6} \mathrm{H}_{4}\right) \mathrm{CH}\left(4-\mathrm{BrC}_{6} \mathrm{H}_{4}\right)-$<smiles>[Al]C=NC1CCCCC1N=CBr</smiles>

L16, $\mathrm{Ar}=2-\mathrm{HOC}_{6} \mathrm{H}_{4}$

L17, $\mathrm{Ar}=2-\mathrm{MeOC}_{6} \mathrm{H}_{4}$

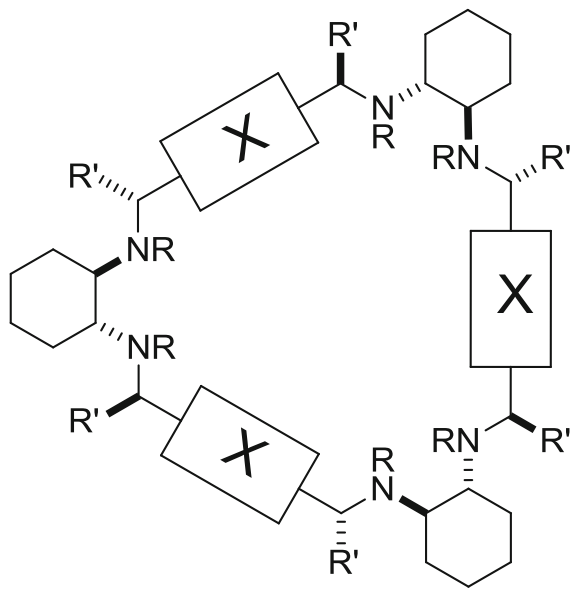

L18, $R=R^{\prime}=H, X=$

L19, $R=R^{\prime}=H, X=$

L20, $R=R^{\prime}=H, X=$<smiles>C=Cc1ccc(C=CC)cc1-c1cc(C(C)(C)C)ccc1O</smiles>

L21, $\mathrm{R}=\mathrm{H}, \mathrm{R}^{\prime}=\mathrm{Me}, \mathrm{X}=$

L22, $R=H, R^{\prime}=P h, X=$

L23, $R=M e, R^{\prime}=H, X=$

L24, $\mathrm{R}=-\left(\mathrm{CH}_{2}\right)_{2} \mathrm{OH}, \mathrm{R}^{\prime}=\mathrm{H}, \mathrm{X}=$
D1, R, R' = H
D2, $\mathrm{R}=\mathrm{Me}, \mathrm{R}^{\prime}=\mathrm{H}$
D3, $\mathrm{R}, \mathrm{R}^{\prime}=\mathrm{Me}$
D4, R, R' = -( $\left.\mathrm{CH}_{2}\right)_{4}$ - (trans)
D5, R, R' = -( $\left.\mathrm{CH}_{2}\right)_{4^{-}}$(cis)
D6, $R, R^{\prime}=$ COOMe
D7, R, R' = COOi-Pr<smiles>[R]C(O)C([R])O</smiles><smiles>[R]C(O)CC([R])O</smiles>

D8, R, R' = H

D9, $\mathrm{R}=\mathrm{Me}, \mathrm{R}^{\prime}=\mathrm{H}$

D10, R, R' = Me

D12, $\mathrm{R}, \mathrm{R}^{\prime}=\mathrm{H}$

D13, $\mathrm{R}=\mathrm{H}, \mathrm{R}^{\prime}=\mathrm{OH}$

D14, R = H, R' = 2- $\mathrm{HOC}_{6} \mathrm{H}_{4}$

\section{Results and discussion}

Effect of the structure of the amine ligand

on the efficiency of the catalytic system

We initially examined the effect of ligand structure on the yield and enantioselectivity of Zn-catalyzed hydrosilylation of 4-methylacetophenone (Fig. 3). The catalyst load in all cases was $3.5 \mathrm{~mol} \%$. Diphenylsilane was used as the reducing agent and all reactions were carried out in dry and degassed toluene for $24 \mathrm{~h}$ at room temperature.

Among 24 ligands tested nine (L4, L5, L9, L12-L14, L16, L22, and L23) did not promote hydrosilylation under these conditions (Fig. 3, entries 4, 5, 9, 12-14, 16, and 22-23), resulting in recovery of the starting material. These non-effective ligands contain either polar or bulky groups 
Fig. 3 Effect of ligand structure on conversion and enantioselectivity of hydrosilylation of 4-methylacetophenone. Reaction conditions: $3.5 \mathrm{~mol} \%$ catalyst, 1.2 equiv. silane, reaction time $24 \mathrm{~h}$, toluene, $\mathrm{RT}$; conversions and enantiomeric excesses were determined by HPLC with a Chiralpak IA column, average of two runs

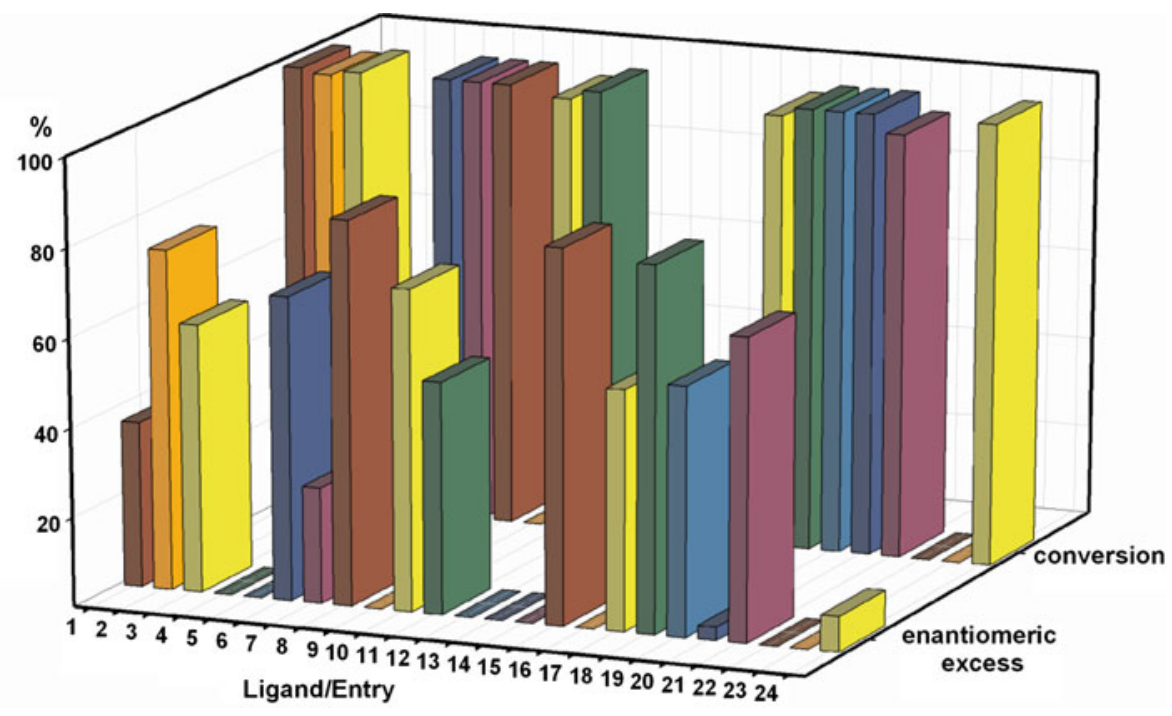

in different positions on the benzene ring (L4, L5, L9, L16) or have an additional substituent on the nitrogen atom (L13, L14, L23).

Ligands having additional hydroxy (L4) or methoxy groups (L5) in the para position of the benzene ring were inactive in the hydrosilylation reaction, in contrast with ligand L6, with dimethylamino groups in the para positions (Fig. 3, entry 6). It is interesting that the conformationally labile ligands $\mathbf{L 7}$ and L20 with hydroxy groups in the ortho positions which do not form planar complexes with zinc, are, nevertheless, active hydrosilylation catalysts, with conversions of the substrate almost quantitative, although with low enantiomeric excess of the product (Fig. 3, entries 7 and 20).

Catalytically inactive acyclic (L13 and L14) and macrocyclic (L23) ligands are distinguished by additional methyl substituents on the nitrogen atoms. This indicates that the presence of an $\mathrm{N}-\mathrm{H}$ bond in the ligand structure is essential if the reaction is to proceed. Macrocyclic ligand L24, characterized by the presence of hydroxyethyl substituents on the nitrogen atoms, is an exception. Although it activates the catalyst, the enantioselectivity obtained by use of L24 was low and the best result was obtained when six equivalents of $\mathrm{ZnEt}_{2}$ per one equivalent of the ligand were used (ee $15 \%$, conversion of the substrate $99 \%$ ).

Although salen L16 is catalytically inactive, apparently because of the formation of dimeric species [41] its methoxy derivative $\mathbf{L 1 7}$ promotes the hydrosilylation reaction (Fig. 3, entry 17 ).

The presence of an $\mathrm{N}-\mathrm{H}$ hydrogen atom is a prerequisite for catalytic activity; it is, however, not sufficient for catalysis of the hydrosilylation reaction. In secondary diamine L12, an aniline derivative, delocalization of the nitrogen lone pair to the aromatic ring reduces its coordination ability. More importantly, the specific, almost parallel conformation of the aromatic rings in $\mathbf{L 1 2}$ does not allow the zinc atom to be included in the coordination space of the nitrogen atom [42]. This makes the ligand ineffective for catalysis.

In $\mathbf{L 2 2}$ the phenyl groups on the benzylic carbon atoms occupy positions perpendicular to the average plane of the macrocycle [43, 44] and thus strongly stabilize the triangular conformation of L22. Steric crowding and lack of flexibility of the ligand apparently prohibit substrate binding. In contrast with L22, less sterically crowded L21 catalyses the hydrosilylation reaction efficiently (Fig. 3, entry 21).

The enantiomeric excess of the product obtained by use of $\mathbf{L 1 5}$ is the second best for all ligands tested; however, conversion of the substrate does not exceed $5 \%$ (Fig. 3, entry 15). Therefore $\mathbf{L 1 5}$ is not efficient as a ligand.

These results clearly show that both overcrowding and too much space around the coordination site make the efficiency of the catalytic system problematic. Ligands L1 and $\mathbf{L} \mathbf{2}$ differ in substitution of nitrogen atoms. Although both ligands are catalytically active in terms of conversion of the substrate (over 99 and $98 \%$, respectively for L1 and L2; Fig. 3, entries 1 and 2), the enantioselectivity of the reaction with use of $N$-benzyl derivative $\mathbf{L} 2$ is ca twice as high (76\%) as that obtained by use of the simple $N$-methyl DACH derivative L1 (37 \%) and may be further increased if the diamine is part of a regular trianglamine $\mathbf{L 1 8}$ structure. In this case conversion of the substrate is quantitative and the macrocyclic structure of the ligand results in an increase in the enantioselectivity $(82 \%)$ of the process (Fig. 3, entry 18).

Efficiency of the catalyst may be further tuned by introduction of additional coordinating groups, although with varying results. Replacement of the phenyl group by a 2-pyridyl group (L11) results in an increase of conversion 
Fig. 4 Structures of stable conformers $\mathbf{L 8} \mathrm{ZnMe}_{2}$ (a) and $\mathbf{L 8} \mathrm{ZnMe}_{2}$ (b) calculated at the PBE0/6-311++G(d,p) level of theory (some hydrogen atoms were omitted for clarity; distances are in $\AA$ ) (a)

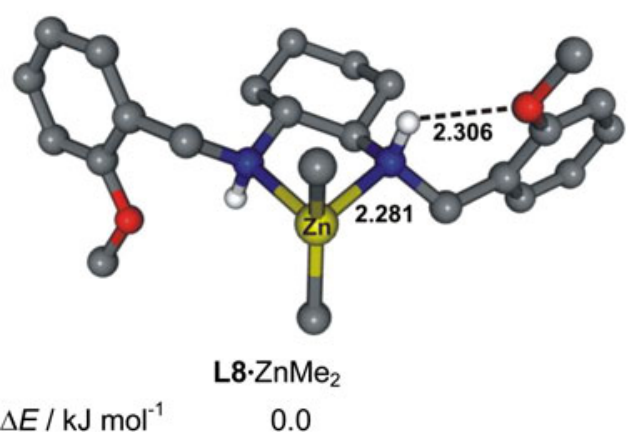

(b)

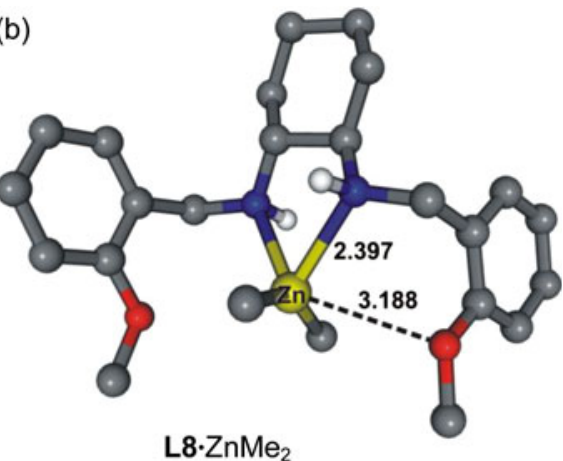

19.7 at the expense of enantioselectivity (52\%), in comparison with L2 (Fig. 3, entry 11). Introduction of a diphenylphosphine group in the ligand $\mathbf{L 1 0}$ structure results in an increase of enantioselectivity (to $72 \%$; Fig. 3, entry 10), but enantioselectivity is still lower than with use of $\mathbf{L 2}$. The best result in terms of product enantioselectivity ( $86 \%$ ) and conversion of the substrate ( $>99 \%$ ) was obtained by use of methoxy-substituted ligand L8 (Fig. 3, entry 8). Direct $(\mathrm{Me}) \mathrm{O} \cdots \mathrm{Zn}$ interactions are excluded in the complex of $\mathbf{L 8}$ and dialkylzinc. According to computation at the PBE0/6-311++G(d,p) level [45] the stable conformer L8 $\mathrm{ZnMe}_{2}$ (Fig. 4b), in which a direct $\mathrm{O} \cdots \mathrm{Zn}$ interaction is possible, is of higher energy $\left(19.7 \mathrm{~kJ} \mathrm{~mol}^{-1}\right)$ than the conformer with an intramolecular $\mathrm{NH} \cdots \mathrm{O}(\mathrm{Me})$ hydrogen bond (Fig. 4).

Screening of the ligands was conducted in conjunction with screening of the type of silane used as the reducing agent. Selected results are shown in Table 1 .

In the test reaction none of the silanes tested (PMHS, $\mathrm{Et}_{3} \mathrm{SiH},(\mathrm{EtO})_{3} \mathrm{SiH}, \mathrm{Me}_{2} \mathrm{PhSiH}$, and $\mathrm{PhSiH}_{3}$ ) performed better than diphenylsilane in combination with L8. The decrease of enantioselectivity was small when $(\mathrm{EtO})_{3} \mathrm{SiH}$ was combined with $\mathbf{L 8}$ (drop to $85 \%$; Table 1, entry 2) or $\mathbf{L 1 8}$ (drop to $81 \%$; Table 1, entry 4), compared with the combination of $\mathrm{Ph}_{2} \mathrm{SiH}_{2}$ and $\mathbf{L 8}$. In other cases, however, it was significant. Among silanes tested, two $\left(\mathrm{Et}_{3} \mathrm{SiH}\right.$, $\mathrm{Me}_{2} \mathrm{PhSiH}$ ) did not promote hydrosilylation under the above mentioned conditions. In all cases discussed in this paragraph the product of hydrosilylation had $S$ absolute configuration.

\section{Hydrosilylation of aryl-alkyl or aryl-aryl ketones catalyzed by $[\mathrm{Zn}(\boldsymbol{L} \mathbf{8})]$ or $[\mathrm{Zn}(\boldsymbol{L 1 8})]$ complexes}

Having established L8 and L18 as the best performing chiral ligands, a variety of alkyl-aryl and aryl-aryl ketones were reduced by using $3.5 \mathrm{~mol} \%$ catalyst, 1.2 equiv. silane, and toluene as solvent. The most interesting results are summarized in Table 2.
Table 1 Effect of silane structure on conversion and enantioselectivity of the hydrosilylation of 4-methylacetophenone

\begin{tabular}{|c|c|c|c|c|}
\hline Entry & Silane & Ligand & Conversion/\% & ee $/ \%$ \\
\hline 1 & PMHS & L2 & $>99$ & 55 \\
\hline 2 & $(\mathrm{EtO})_{3} \mathrm{SiH}$ & L8 & $>99$ & 85 \\
\hline 3 & $\mathrm{Ph}_{2} \mathrm{SiH}_{2}$ & L8 & $>99$ & 86 \\
\hline 4 & PMHS & L11 & $>99$ & 41 \\
\hline 5 & PMHS & L18 & 99 & 81 \\
\hline 6 & $(\mathrm{EtO})_{3} \mathrm{SiH}$ & L18 & $>99$ & 78 \\
\hline 7 & $\mathrm{Et}_{3} \mathrm{SiH}$ & L18 & Traces & 7 \\
\hline 8 & $\mathrm{PhSiH}_{3}$ & L18 & $>99$ & 78 \\
\hline 9 & $\mathrm{Me}_{2} \mathrm{PhSiH}$ & L18 & 0 & 0 \\
\hline
\end{tabular}

3.5 mol \% catalyst, 1.2 equiv. silane, reaction time $24 \mathrm{~h}$, toluene, RT; conversion and enantiomeric excess were determined by HPLC with a Chiralpak IA column (average of two runs)

Of all substrates ethyl phenyl ketone gave the best results in terms of enantioselectivity and yield of the reaction (ee up to $86 \%$; Table 2, entries 2 and 3). The presence of a bulky alkyl group in cyclohexyl phenyl ketone resulted in a small decrease of enantioselectivity (83\%; Table 2, entry 5). For both compounds, use of macrocycle $\mathbf{L 1 8}$ provided better results than the use of acyclic ligand $\mathbf{L 8}$.

Enantiomeric purity varied significantly when cyclic ketones, 1-tetralone, 2-tetralone, and 1-indanone, were used as the substrates. The best result was obtained in the reduction of 1-tetralone by diphenylsilane in the presence of ligand L8 (ee $84 \%$, yield $91 \%$; Table 2, entry 16). Better yield $(97 \%)$ at the expense of enantioselectivity (drop to $71 \%$ ) was achieved when zinc complex with $\mathbf{L 1 8}$ was used as the catalyst for reduction of 1-tetralone (Table 2, entry 17). The opposite trend was observed on use of 1-indanone-higher enantiomeric excess (69\%) was obtained by use of $\mathbf{L 8}$ (Table 2, entry 15). 2-Tetralone was an exception-because of the low stereodifferentation of both faces of the substrate molecule, enantioselectivity of the reaction did not exceed $40 \%$ when $\mathbf{L 8}$ was used as ligand (Table 2, entry 18). 
Table 2 [ $\mathrm{Zn}($ Diamine)]-catalyzed hydrosilylation of prochiral ketones

\begin{tabular}{|c|c|c|c|c|}
\hline Entry & Substrate & Silane & Ligand & ee $/ \%[\text { yield } / \%]^{2}$ \\
\hline 1 & $\mathrm{C}_{6} \mathrm{H}_{5} \mathrm{COC}_{2} \mathrm{H}_{5}$ & $\mathrm{Ph}_{2} \mathrm{SiH}_{2}$ & L8 & $74(S)^{\mathrm{b}}$ \\
\hline 2 & $\mathrm{C}_{6} \mathrm{H}_{5} \mathrm{COC}_{2} \mathrm{H}_{5}$ & $\mathrm{Ph}_{2} \mathrm{SiH}_{2}$ & L18 & $85(S)$ \\
\hline 3 & $\mathrm{C}_{6} \mathrm{H}_{5} \mathrm{COC}_{2} \mathrm{H}_{5}$ & PMHS & L18 & 86 [71] $(S)$ \\
\hline 4 & $\mathrm{C}_{6} \mathrm{H}_{5} \mathrm{COC}_{6} \mathrm{H}_{11}$ & $\mathrm{Ph}_{2} \mathrm{SiH}_{2}$ & $\mathbf{L 8}$ & $74(S)$ \\
\hline 5 & $\mathrm{C}_{6} \mathrm{H}_{5} \mathrm{COC}_{6} \mathrm{H}_{11}$ & $\mathrm{Ph}_{2} \mathrm{SiH}_{2}$ & L18 & $83(S)$ \\
\hline 6 & $4-\mathrm{MeO}-\mathrm{C}_{6} \mathrm{H}_{4} \mathrm{COCH}_{3}$ & $\mathrm{Ph}_{2} \mathrm{SiH}_{2}$ & L8 & 79 [44] $(S)$ \\
\hline 7 & $4-\mathrm{MeO}-\mathrm{C}_{6} \mathrm{H}_{4} \mathrm{COCH}_{3}$ & $\mathrm{Ph}_{2} \mathrm{SiH}_{2}$ & L18 & $43[60](S)$ \\
\hline 8 & $4-\mathrm{F}-\mathrm{C}_{6} \mathrm{H}_{4} \mathrm{COCH}_{3}$ & PMHS & L18 & $78(S)$ \\
\hline 9 & $4-\mathrm{F}-\mathrm{C}_{6} \mathrm{H}_{4} \mathrm{COCH}_{3}$ & $\mathrm{PhSiH}_{3}$ & L18 & $81(S)$ \\
\hline 10 & $4-\mathrm{F}-\mathrm{C}_{6} \mathrm{H}_{4} \mathrm{COCH}_{3}$ & $\mathrm{Ph}_{2} \mathrm{SiH}_{2}$ & L18 & $82[63](S)$ \\
\hline 11 & $4-\mathrm{NC}-\mathrm{C}_{6} \mathrm{H}_{4} \mathrm{COCH}_{3}$ & $\mathrm{Ph}_{2} \mathrm{SiH}_{2}$ & L8 & $80[26](S)$ \\
\hline 12 & $4-\mathrm{NC}-\mathrm{C}_{6} \mathrm{H}_{4} \mathrm{COCH}_{3}$ & PMHS & L18 & $71(S)$ \\
\hline 13 & $4-\mathrm{NC}-\mathrm{C}_{6} \mathrm{H}_{4} \mathrm{COCH}_{3}$ & $\mathrm{PhSiH}_{3}$ & L18 & $69(S)$ \\
\hline 14 & Indanone & $\mathrm{Ph}_{2} \mathrm{SiH}_{2}$ & L8 & $32(S)$ \\
\hline 15 & Indanone & $\mathrm{Ph}_{2} \mathrm{SiH}_{2}$ & L18 & 69 [75] $(S)$ \\
\hline 16 & 1-Tetralone & $\mathrm{Ph}_{2} \mathrm{SiH}_{2}$ & L8 & 84 [91] (S) \\
\hline 17 & 1-Tetralone & $\mathrm{Ph}_{2} \mathrm{SiH}_{2}$ & L18 & 71 [97] $(S)$ \\
\hline 18 & 2-Tetralone & $\mathrm{Ph}_{2} \mathrm{SiH}_{2}$ & L8 & 39 [75] $(S)$ \\
\hline 19 & 2-Tetralone & $\mathrm{Ph}_{2} \mathrm{SiH}_{2}$ & L18 & $12[62](S)$ \\
\hline 20 & $\mathrm{C}_{6} \mathrm{H}_{5} \mathrm{COCF}_{3}$ & $\mathrm{Ph}_{2} \mathrm{SiH}_{2}$ & L8 & 15 [43] $(R)$ \\
\hline 21 & $\mathrm{C}_{6} \mathrm{H}_{5} \mathrm{COCF}_{3}$ & $\mathrm{Ph}_{2} \mathrm{SiH}_{2}$ & L18 & $19[54](R)$ \\
\hline 22 & $\mathrm{C}_{6} \mathrm{H}_{5} \mathrm{COCF}_{3}$ & PMHS & L18 & $11[50](R)$ \\
\hline 23 & $2,4,6-\mathrm{Me}_{3} \mathrm{C}_{6} \mathrm{H}_{2} \mathrm{COCF}_{3}$ & $\mathrm{Ph}_{2} \mathrm{SiH}_{2}$ & $\mathbf{L 8}$ & $6(R)$ \\
\hline 24 & $2,4,6-\mathrm{Me}_{3} \mathrm{C}_{6} \mathrm{H}_{2} \mathrm{COCF}_{3}$ & PMHS & L18 & $19[52](R)$ \\
\hline 25 & $4-\mathrm{F}-\mathrm{C}_{6} \mathrm{H}_{4} \mathrm{COCF}_{3}$ & $\mathrm{Ph}_{2} \mathrm{SiH}_{2}$ & L8 & $6(R)$ \\
\hline 26 & $4-\mathrm{F}-\mathrm{C}_{6} \mathrm{H}_{4} \mathrm{COCF}_{3}$ & PMHS & L18 & $9[34](R)$ \\
\hline 27 & $3,5-\left(\mathrm{CF}_{3}\right)_{2}-\mathrm{C}_{6} \mathrm{H}_{3} \mathrm{COCH}_{3}$ & $\mathrm{Ph}_{2} \mathrm{SiH}_{2}$ & $\mathbf{L 8}$ & $68[76](S)$ \\
\hline 28 & $3,5-\left(\mathrm{CF}_{3}\right)_{2}-\mathrm{C}_{6} \mathrm{H}_{3} \mathrm{COCH}_{3}$ & PMHS & L18 & $16[64](S)$ \\
\hline 29 & $3-\mathrm{Me}-\mathrm{C}_{6} \mathrm{H}_{4} \mathrm{COC}_{6} \mathrm{H}_{5}$ & $\mathrm{Ph}_{2} \mathrm{SiH}_{2}$ & L8 & $13[81](S)$ \\
\hline 30 & $3-\mathrm{Me}-\mathrm{C}_{6} \mathrm{H}_{4} \mathrm{COC}_{6} \mathrm{H}_{5}$ & $\mathrm{Ph}_{2} \mathrm{SiH}_{2}$ & L18 & $1(S)$ \\
\hline 31 & $4-\mathrm{Me}-\mathrm{C}_{6} \mathrm{H}_{4} \mathrm{COC}_{6} \mathrm{H}_{5}$ & $\mathrm{Ph}_{2} \mathrm{SiH}_{2}$ & $\mathbf{L 8}$ & $7(S)$ \\
\hline 32 & $4-\mathrm{Me}-\mathrm{C}_{6} \mathrm{H}_{4} \mathrm{COC}_{6} \mathrm{H}_{5}$ & $\mathrm{Ph}_{2} \mathrm{SiH}_{2}$ & L18 & $11[92](S)$ \\
\hline 33 & $2-\mathrm{Cl}-\mathrm{C}_{6} \mathrm{H}_{4} \mathrm{COC}_{6} \mathrm{H}_{5}$ & $\mathrm{Ph}_{2} \mathrm{SiH}_{2}$ & $\mathbf{L 8}$ & $62(R)$ \\
\hline 34 & $2-\mathrm{Cl}-\mathrm{C}_{6} \mathrm{H}_{4} \mathrm{COC}_{6} \mathrm{H}_{5}$ & $\mathrm{Ph}_{2} \mathrm{SiH}_{2}$ & L18 & $72[84](R)$ \\
\hline 35 & $4-\mathrm{Cl}-\mathrm{C}_{6} \mathrm{H}_{4} \mathrm{COC}_{6} \mathrm{H}_{5}$ & $\mathrm{Ph}_{2} \mathrm{SiH}_{2}$ & $\mathbf{L 8}$ & $26(R)$ \\
\hline 36 & $4-\mathrm{Cl}-\mathrm{C}_{6} \mathrm{H}_{4} \mathrm{COC}_{6} \mathrm{H}_{5}$ & $\mathrm{Ph}_{2} \mathrm{SiH}_{2}$ & L18 & 26 [47] $(R)$ \\
\hline
\end{tabular}

$3.5 \mathrm{~mol} \%$ catalyst, 1.2 equiv. silane, reaction time $24 \mathrm{~h}$, toluene, RT; conversion and enantiomeric excess were determined by HPLC with a Chiralpak IA column (average of two runs)

a Isolated yield

b Absolute configuration

4-Methoxyacetophenone, 4-cyanoacetophenone, and 4-fluoroacetophenone gave the products of hydrosilylation with good ee (79-82 \%; Table 2, entries 6-7 and 10-13).

Pharmaceutically important aryl trifluoromethyl ketones were hydrosilylated with low enantioselectivity (ee $19 \%$; Table 2, entries 21 and 24, and $9 \%$; Table 2, entry 26). The lack of success was in agreement with previously reported data [30]. On the other hand, trifluoromethyl groups attached to the aryl ring affected reaction enantioselectivity to a small extent only. When 3,5-bis(trifluoromethyl)phenyl methyl ketone was used the enantioselectivity of the reaction (up to $68 \%$ ) was over four times more than when phenyl trifluoromethyl ketone was used, and the product was obtained with good chemical yield (76\%; Table 2, entry 27) when $\mathbf{L 8}$ was used as a ligand.

Hydrosilylation of substituted benzophenones gave mixed results (Table 2, entries 29-36). The best result (ee $72 \%$, yield $84 \%$ ) was obtained when 2-chlorobenzophenone was reduced chemoselectively by diphenylsilane with use of L18 (Table 2, entry 34).

\section{Asymmetric activation of the [Zn(diamine)] catalyst}

Use of an activator in the [ $\mathrm{Zn}$ (diamine)]-catalyzed hydrosilylation reactions has the potential to increase both enantioselectivity and the reaction rate. In our study we tested several diol-amine combinations including acyclic ligands L1, L2, macrocycle L18, and diol activators D1-D14 (Figs. 1, 2). Note that L2 was used in either the racemic or enantiomerically pure form.

Standard conditions involved generation of the zinc complex by addition of an equimolar amount of diethylzinc in hexane to a solution of the ligand in toluene (or any other solvent) followed by addition of an equimolar amount of the appropriate diol. After $0.5 \mathrm{~h}$ the ketone and the silane were added and reaction was performed at room temperature for $24 \mathrm{~h}$ and then quenched with methanolic $\mathrm{NaOH}$ solution (Scheme 2). Changing of the order of addition of $\mathrm{ZnEt}_{2}$, diamine, activator, silane, and substrate did not affect enantioselectivity or conversion rate.

Although the nature of the silane had only a negligible effect on the conversion rate and enantioselectivity of the reaction, slightly better results were obtained when diphenylsilane was used as the reducing agent.

The effect of activator structure and the reaction conditions on the efficiency of the catalytic system was studied in the test reaction of hydrosilylation of 4-methylacetophenone. The results are summarized in Table 3.

The effect of amine and diol structure on the enantioselectivity of [ $\mathrm{Zn}$ (diamine)(diol)]-catalyzed hydrosilylation was investigated for two arbitrarily chosen activators D1 and D9. Enantioselectivity obtained for [ $\mathrm{Zn}$ (diamine)D1]catalyzed hydrosilylations ranged from 41 (L1) to $82 \%$ (L18) and increased slightly (to $83 \%$ ) if 2 equiv. D1 were used for 1 equiv. L18 (Table 3, entries 1-4). The presence of the stereogenic center in D9 did not significantly affect the stereoselectivity of the reaction. Comparison of the results obtained for $\mathrm{Zn}(\mathbf{L 1})$ and $\mathrm{Zn}(\mathbf{L 1 8})$ complexes activated by either $(\mathrm{rac}),(R)$, or $(S)$-D9 shows the advantage of 
Table 3 Effect of ligand structure and solvent on the efficiency of $[\mathrm{Zn}$ (diamine)(diol)]-catalyzed hydrosilylation of 4-methylacetophenone

\begin{tabular}{|c|c|c|c|c|c|}
\hline Entry & Solvent & Ligand & Activator & Conversion/\% & $\mathrm{ee} / \%$ \\
\hline 1 & Toluene & L1 & D1 & 100 & 41 \\
\hline 2 & Toluene & $\mathbf{L 2}$ & D1 & 98 & 75 \\
\hline 3 & Toluene & L2 & D1 $^{\mathrm{a}}$ & $>99$ & 78 \\
\hline 4 & Toluene & L18 & D1 & 99 & 82 \\
\hline 5 & Toluene & L1 & $(r a c)-\mathbf{D 9}$ & 100 & 40 \\
\hline 6 & Toluene & L18 & $(r a c)-\mathbf{D 9}$ & 96 & 83 \\
\hline 7 & Toluene & L1 & (R)-D9 & 100 & 41 \\
\hline 8 & Toluene & L18 & $(R)$-D9 & 97 & 73 \\
\hline 9 & Toluene & L18 & $(R)-\mathbf{D 9}^{\mathrm{a}}$ & 92 & 73 \\
\hline 10 & Toluene & L1 & $(S)$-D9 & 100 & 38 \\
\hline 11 & Toluene & L18 & $(S)$-D9 & $>99$ & 81 \\
\hline 12 & THF & L18 & D1 & $>99$ & 81 \\
\hline 13 & $\mathrm{CH}_{2} \mathrm{Cl}_{2}$ & L18 & D1 & $>99$ & 69 \\
\hline 14 & Toluene & L18 & $\mathrm{MeOH}^{\mathrm{b}}$ & 98 & 79 \\
\hline 15 & Toluene & L18 & $\mathrm{MeOH}^{\mathrm{a}}$ & $>99$ & 84 \\
\hline 16 & $\mathrm{MeOH}$ & L18 & None & 97 & 61 \\
\hline 17 & Toluene & $(r a c)-\mathbf{L} 2$ & $(R)-\mathbf{D 2}$ & $>99$ & 4 \\
\hline 18 & Toluene & L2 & $(r a c)-\mathbf{D 2}$ & 99 & 77 \\
\hline 19 & Toluene & None & D6 & 0 & 0 \\
\hline 20 & Toluene & None & $\mathbf{D 6}^{\mathrm{a}}$ & 0 & 0 \\
\hline 21 & Toluene & $(r a c)-\mathbf{L} 2$ & D6 & $>99$ & 5 \\
\hline 22 & Toluene & $\mathbf{L 2}$ & D6 & $>99$ & 72 \\
\hline 23 & Toluene & None & D7 & 0 & 0 \\
\hline 24 & Toluene & $(r a c)-\mathbf{L} \mathbf{2}$ & D7 & $>99$ & 6 \\
\hline
\end{tabular}

$3.5 \mathrm{~mol} \%$ catalyst, 1.2 equiv. diphenylsilane, reaction time $24 \mathrm{~h}$, toluene, RT; conversion and enantiomeric excess were determined by HPLC with a Chiralpak IA column (average of two runs)

a 2 equiv. activator were used

b 1 equiv. $\mathrm{MeOH}$ was used

cyclic over acyclic structure of the amine ligand and in each series similar results were obtained when either $(\mathrm{rac})$-D9 or enantiomerically pure D9 was used as the activator (Table 3, entries 5-11). For [ $\mathrm{Zn}(\mathbf{L 1 8})(\mathbf{D 9} 9)]$-catalyzed hydrosilylations of 4-methylacetophenone, for example, product enantioselectivity was: 83,73 , and $81 \%$ for $(\mathrm{rac})$, $(R)$, and (S)-D9, respectively. The enantioselectivity of the non-activated $[\mathrm{Zn}(\mathbf{L} 18)]$-catalyzed reaction was $82 \%$.

Changing the solvent from toluene to THF or dichloromethane slightly improved conversion in the $[\mathrm{Zn}(\mathbf{L 1 8})$ (D1)]-catalyzed hydrosilylation of 4-methylacetophenone, from 98 to $100 \%$, at the expense of enantioselectivity (drop to 81 or $69 \%$ ee of the product; Table 3, entries 12 and 13). Substituting the diol in the catalyst structure with 2 or 1 equiv. methanol resulted in a 1 and $6 \%$ (respectively for 2 or 1 equiv. $\mathrm{MeOH}$ ) drop in enantioselectivity of the hydrosilylation reaction performed in toluene (Table 3 , entries 14 and 15). The same reaction could be performed in pure methanol (Table 3, entry 16). Although conversion of the substrate was still high, enantiomeric purity of the product decreased substantially (drop to $61 \%$ ). In contrast with the reduction of ketones, a similar reaction performed for imines gave better results in protic solutions than in any non-polar or aprotic media [31].

The stereochemical course of the reaction is controlled by the chirality of the diamine part of catalytically active species. Although use of (rac)-L2 with enantiomerically pure diols D2, D6, and D7 preserved high conversion of the substrate, we observed a substantial decrease of enantioselectivity (Table 3 , entries 17, 21, and 24). Use of enantiomerically pure $\mathbf{L 2}$ with $(\mathrm{rac})$-D2 as the catalytic system provided the product with $77 \%$ ee (Table 3, entry 18). It should be noted that when used alone, the diol or [Zn(diol)] were not catalytically active species (Table 3 , entries 19, 20, and 23).

Full screening of the activators was conducted for $[\mathrm{Zn}(\mathbf{L 1 8})]$-catalyzed hydrosilylation of 4-methylacetophenone. All reaction were carried out in toluene on a $1 \mathrm{mmol}$ scale, using $3.5 \mathrm{~mol} \% \mathbf{L 1 8}$, equimolar amounts of $\mathrm{ZnEt}_{2}$ and the activator, and $1.2 \mathrm{mmol}$ silane. Conversion and enantiomeric excess were determined by HPLC with a Chiralpak IA column. The results are summarized in Fig. 5.

The results show that all combinations of $\mathbf{L 1 8}$ and the activator were catalytically active. As was mentioned above, conversion of the substrate was high (over $92 \%$ ) and enantiomeric excess of the product was usually ca. $80 \%$.

More detailed inspection of the results summarized in Fig. 5 shows that the highest enantioselectivity (ee $85 \%$ ) in the hydrosilylation of 4-methylacetophenone was achieved with trianglamine ligand $\mathbf{L 1 8}$ and $(S)$-D2 or $(S, S)$ D4 as activator, with diphenylsilane as reducing agent (Fig. 5, entries 2 and 4). Replacing (S)-D2 or (S,S)-D4 by the simple diol D1 resulted in a $3 \%$ drop of enantioselectivity, with unchanged conversion (Table 3, entry 4). Replacing the aliphatic alcohol by phenol as activator had no profound effect on either enantioselectivity or conversion of the substrate. The product of hydrosilylation had $S$ absolute configuration irrespective of the amine-alcohol combination used.

\section{Summary}

In this work we tested a wide range of DACH-based amine ligands, activators, and reactants for asymmetric hydrosilylation of prochiral ketones. The $\mathbf{L 8}-\mathrm{ZnEt}_{2}$ and $\mathbf{L 1 8}-\mathrm{ZnEt}_{2}$ (1:1) complexes catalyze the hydrosilylation of 4-methylacetophenone by diphenylsilane in toluene solution, with 
Fig. 5 Effect of activator structure on enantioselectivity in $[\mathrm{Zn}(\mathbf{L 1 8})]$-catalyzed hydrosilylation of 4-methylacetophenone. First row represents achiral or racemic activators, second and third rows summarize results obtained for activators of $R$ or $S$ absolute configuration at the stereogenic centers, respectively

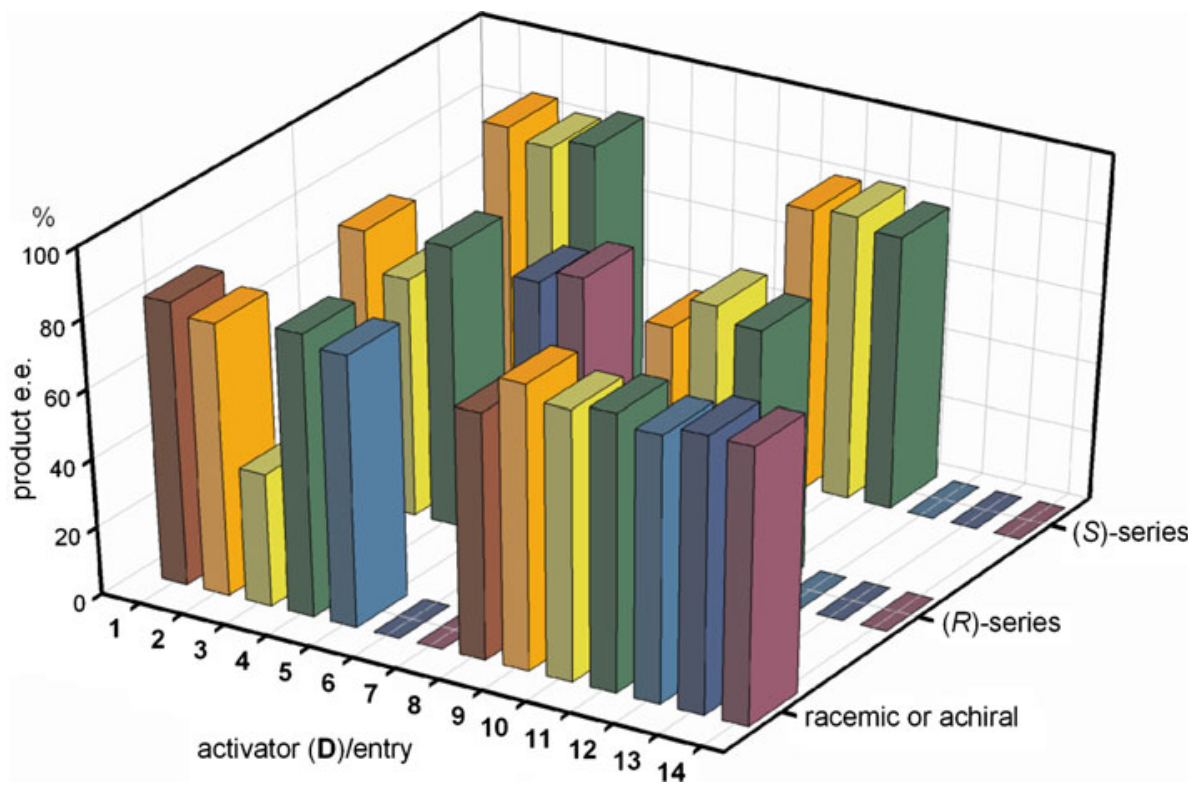

up to $86 \%$ ee of the product. The enantioselectivity is higher than that with use of other acyclic or cyclic ligands. Because both $\mathbf{L 8}$ and $\mathbf{L 1 8}$ can be conveniently prepared by a one-pot procedure from the inexpensive tartrate salt of $\mathrm{DACH}$ and $o$-anisole or terephthalaldehyde, the $\mathrm{Zn}$ complexes of $\mathbf{L 8}$ and $\mathbf{L 1 8}$ are good alternatives to previously reported chiral catalysts.

A small effect of activator structure on enantioselectivity and significant large increases in the conversion and yield of the reaction seem consistent with the mechanism postulated by Bette et al. [39] and by us, supported by computational experiments [46]. According to this proposal the diol moiety does not sterically affect the substrate in the transition state; it does, however, activate the zinc ion acting as catalyst $[39,40]$.

\section{Experimental}

NMR spectra were recorded on Bruker BioSpin 400 $(400 \mathrm{MHz})$ or Varian MR $300(300 \mathrm{MHz})$ instruments at $25{ }^{\circ} \mathrm{C}$ using $\mathrm{CDCl}_{3}$ as solvent. Chemical shifts are reported in ppm relative to the TMS peak $\left({ }^{1} \mathrm{H}\right.$ and ${ }^{13} \mathrm{C}$ NMR spectra). Spectral assignments were obtained by analysis of chemical shifts and by comparison with literature data. Mass spectra were recorded on an AMD-402 spectrometer. HPLC analysis was performed at room temperature with an Hitachi LaChrom Elite system equipped with a Chiralpak IA column. Details of HPLC separation of the enantiomers are given in the Supplementary Information (Table SI1). Absolute configurations of the products were determined by comparison of measured optical rotation with the literature data [47-62].
Ligands L1-L3, L5, L7-L18, L21-L24 were prepared by procedures reported in the literature [24-30, 43, 63-71]. Ligands L4, L4, L19, and L20 were obtained from the corresponding imines $[28,65,72]$, by use of a procedure reported elsewhere [24]. NMR spectra and melting points for all ligands and products of hydrosilylation reactions were in agreement with literature data (systematic names of L1-L3, L5, L7-L18, L21-L24 and some physical data are given in the Supplementary Information, Table SI2) [2430, 41, 43, 47-71]. Diols D1-D14 were commercial products.

$(R, R)-N, N^{\prime}$-Bis[(4-hydroxyphenyl)methyl]-1,2cyclohexanediamine $\left(\mathbf{L} 4, \mathrm{C}_{20} \mathrm{H}_{26} \mathrm{~N}_{2} \mathrm{O}_{2}\right)$

Yield $86 \%$; white solid; m.p.: $141-144{ }^{\circ} \mathrm{C}$ (ethyl acetatehexane); ${ }^{1} \mathrm{H}$ NMR (400 MHz, $\mathrm{CDCl}_{3}$ ): $\delta=7.11-7.08$ (m, $4 \mathrm{H}), 6.79-6.72(\mathrm{~m}, 4 \mathrm{H}), 3.79(\mathrm{~d}, J=12.7 \mathrm{~Hz}, 2 \mathrm{H}), 3.51$ $(\mathrm{d}, J=12.8 \mathrm{~Hz}, 2 \mathrm{H}), 3.27(\mathrm{~s}, 2 \mathrm{H}), 2.26-2.24(\mathrm{~m}, 2 \mathrm{H})$, $2.17-2.13(\mathrm{~m}, 2 \mathrm{H}), 2.06(\mathrm{~s}, 2 \mathrm{H}), 1.75-1.73(\mathrm{~m}, 2 \mathrm{H})$, $1.42-1.35$ (m, 4H) ppm; ${ }^{13} \mathrm{C}$ NMR (101 MHz, $\left.\mathrm{CD}_{3} \mathrm{OD}\right)$ : $\delta=158.3,131.1,129.7,116.5,60.5,50.0,30.7,25.8 \mathrm{ppm}$; IR (KBr): $\bar{v}=3,368,3,295,3,234,2,940,1,610,1,598$, 1,516, 1,247, 996, $829 \mathrm{~cm}^{-1}$; HR-EI-MS $(\mathrm{m} / \mathrm{z})$ : $[\mathrm{M}]^{+}$calcd for $\mathrm{C}_{20} \mathrm{H}_{26} \mathrm{~N}_{2} \mathrm{O}_{2}$ 326.4326, found 326.4350 .

\section{$(R, R)-N, N$ '-Bis[(4-dimethylaminophenyl)methyl]-1,2-} cyclohexanediamine $\left(\mathbf{L 6}, \mathrm{C}_{24} \mathrm{H}_{36} \mathrm{~N}_{4}\right)$

Yield $83 \%$; white solid; m.p.: $140-146{ }^{\circ} \mathrm{C}$ (ethyl acetatehexane); ${ }^{1} \mathrm{H}$ NMR (300 MHz, $\left.\mathrm{CDCl}_{3}\right): \delta=7.12-6.97$ (m, $4 \mathrm{H}), 6.65-6.50(\mathrm{~m}, 4 \mathrm{H}), 3.90-3.86(\mathrm{~m}, 2 \mathrm{H}), 3.85-3.81(\mathrm{~m}$, $2 \mathrm{H}), 2.95-2.91(\mathrm{~s}, 12 \mathrm{H}), 2.43-2.39(\mathrm{~m}, 2 \mathrm{H}), 1.92-1.85$ $(\mathrm{m}, 2 \mathrm{H}), 1.84-1.80(\mathrm{~m}, 2 \mathrm{H}), 1.69-1.65(\mathrm{~m}, 2 \mathrm{H}), 1.38-1.34$ $(\mathrm{m}, 2 \mathrm{H}), 1.33-1.29(\mathrm{~m}, 2 \mathrm{H}) \mathrm{ppm} ;{ }^{13} \mathrm{C}$ NMR $(75 \mathrm{MHz}$, $\left.\mathrm{CDCl}_{3}\right): \delta=160.7,151.7,129.2,124.9,111.5,73.9,40.2$, 
33.4, 24.7 ppm; IR (KBr): $\bar{v}=3,430,2,920,2,852,2,826$, $1,633,1,610,1,528,1,370,1,181,807 \mathrm{~cm}^{-1}$; HR-EI-MS $(m / z):[\mathrm{M}]^{+}$calcd for $\mathrm{C}_{24} \mathrm{H}_{36} \mathrm{~N}_{4} 380.5694$, found 380.5701 .

\section{$(2 R, 3 R, 16 R, 17 R, 30 R, 31 R)-1,4,15,18,29,32-H e x a a z a-$} $(2,3: 16,17: 30,31)$-tributano-(8,11:22,25:36,39)-trietheno$1,2,3,4,5,14,15,16,17,18,19,28,29,30,31,32,33,42$ octadecahydro[42] annulene $\left(\mathbf{L 1 9}, \mathrm{C}_{54} \mathrm{H}_{72} \mathrm{~N}_{6}\right)$

Yield $84 \%$; white solid: m.p.: $>320{ }^{\circ} \mathrm{C}$ (dichloromethanehexane); ${ }^{1} \mathrm{H}$ NMR $\left(300 \mathrm{MHz}, \mathrm{CDCl}_{3}\right): \delta=7.25(\mathrm{~s}, 6 \mathrm{H})$, $6.53(\mathrm{~d}, J=15.2 \mathrm{~Hz}, 6 \mathrm{H}), 6.22-6.16(\mathrm{~m}, 6 \mathrm{H}), 3.29-3.25$ $(\mathrm{m}, 6 \mathrm{H}), 3.19-3.15(\mathrm{~m}, 6 \mathrm{H}), 2.55-2.49(\mathrm{~m}, 6 \mathrm{H}), 1.72(\mathrm{~s}$, $6 \mathrm{H}), 1.69-1.61(\mathrm{~m}, 6 \mathrm{H}), 1.52-1.45(\mathrm{~m}, 6 \mathrm{H}), 1.44-1.34(\mathrm{~m}$, $12 \mathrm{H}) \mathrm{ppm} ;{ }^{13} \mathrm{C} \mathrm{NMR}\left(126 \mathrm{MHz}, \mathrm{CDCl}_{3}\right): \delta=136.3$, 130.5, 128.8, 126.4, 126.1, 61.1, 49.1, 49.0, 31.4, $25.0 \mathrm{ppm}$; IR (KBr): $\bar{v}=3,424,3,296,2,928,2,854$, 2,370, 1,757, 1,450, 1,238, 1,120, 1,050,964, $750 \mathrm{~cm}^{-1}$; HR-EI-MS $(\mathrm{m} / \mathrm{z}):[\mathrm{M}]^{+}$calcd for $\mathrm{C}_{54} \mathrm{H}_{72} \mathrm{~N}_{6}$ 805.1897, found 805.1905 .

$(2 R, 3 R, 11 R, 12 R, 20 R, 21 R)-1,4,10,13,19,22-H e x a a z a-$

(2,3:11,12:20,21)-tris(tetramethylene)-7,16,25-trihydroxy-

(6,8:15,17:24,26)-tris(2-tert-butyl-1-propen-3-yl)-

$1,2,3,4,5,9,10,11,12,13,14,18,19,20,21,22,23,27$ -

octadecahydro[27] annulene (L20, $\left.\mathrm{C}_{54} \mathrm{H}_{84} \mathrm{~N}_{6} \mathrm{O}_{3}\right)$

Yield $93 \%$; glass; ${ }^{1} \mathrm{H}$ NMR (400 $\left.\mathrm{MHz}, \mathrm{CDCl}_{3}\right): \delta=7.09$ $(\mathrm{s}, 6 \mathrm{H}), 5.05(\mathrm{~s}, 3 \mathrm{H}), 3.81(\mathrm{~m}, 12 \mathrm{H}), 2.53-2.51(\mathrm{~m}, 6 \mathrm{H})$, $1.96(\mathrm{~s}, 6 \mathrm{H}), 1.69-1.61(\mathrm{~m}, 6 \mathrm{H}), 1.53-1.45(\mathrm{~m}, 6 \mathrm{H})$, 1.44-1.34 (m, 39H) ppm; ${ }^{13} \mathrm{C}$ NMR (75 MHz, $\left.\mathrm{CDCl}_{3}\right)$ : $\delta=154.5,154.0,140.8,125.0,123.9,60.3,48.8,48.2$, 33.8, 31.6, 31.4, 30.8, $24.8 \mathrm{ppm}$; IR (KBr): $\bar{v}=3,269$, 2,950, 2,858, 1,609, 1,484, 1,362, 1,215 cm $\mathrm{cm}^{-1}$; HR-EI-MS $(m / z):[\mathrm{M}]^{+}$calcd for $\mathrm{C}_{54} \mathrm{H}_{84} \mathrm{~N}_{6} \mathrm{O}_{3}$ 865.6605, found 865.6596 .

\section{General procedure for Zn(diamine)]-catalyzed hydrosilylation of ketones}

In a $5-\mathrm{cm}^{3}$ round-bottomed flask $12.5 \mathrm{~mm}^{3} \mathrm{ZnEt}_{2}(1 \mathrm{M}$ in hexane, $0.0125 \mathrm{mmol}$ ) and the appropriate chiral ligand $(0.0125 \mathrm{mmol})$ were dissolved in $1.5 \mathrm{~cm}^{3}$ freshly distilled toluene and stirred under an argon atmosphere for $30 \mathrm{~min}$. The corresponding ketone $(0.344 \mathrm{mmol})$, or its solution in $1 \mathrm{~cm}^{3}$ toluene, and the silane $(0.413 \mathrm{mmol})$ were then added to the mixture. The resulting solution was stirred at room temperature for $24 \mathrm{~h}$. $\mathrm{NaOH}\left(1 \mathrm{M}\right.$ in $\left.\mathrm{MeOH} ; 1 \mathrm{~cm}^{3}\right)$ was then added with vigorous stirring. The reaction mixture was stirred for an additional hour at room temperature and then the solvents were evaporated. The residue was dissolved in a mixture of $10 \mathrm{~cm}^{3} \mathrm{H}_{2} \mathrm{O}$ and $1 \mathrm{~cm}^{3} 10 \% \mathrm{HCl}$ and extracted with diethyl ether $\left(3 \times 10 \mathrm{~cm}^{3}\right)$. The combined organic extracts were washed with saturated aqueous $\mathrm{NaHCO}_{3}$ solution, $\mathrm{H}_{2} \mathrm{O}$, and brine, dried over anhydrous $\mathrm{MgSO}_{4}$, and concentrated under vacuum. The product was purified by column chromatography on silica gel with hexane-EtOAc (10:1) as eluent.

\section{General procedure for Zn(diamine)(diol)]-catalyzed hydrosilylation of 4-methylacetophenone}

In a $5-\mathrm{cm}^{3}$ round-bottomed flask $12.5 \mathrm{~mm}^{3} \mathrm{ZnEt}_{2}(1 \mathrm{M}$ in hexane, $0.0125 \mathrm{mmol})$, the appropriate chiral ligand $(0.0125 \mathrm{mmol})$, and the diol $(0.0125 \mathrm{mmol})$ were dissolved in $1.5 \mathrm{~cm}^{3}$ freshly distilled toluene and stirred under an argon atmosphere for $30 \mathrm{~min}$. 4-Methylacetophenone $(0.344 \mathrm{mmol})$ and silane $(0.413 \mathrm{mmol})$ were then added to the mixture. The resulting solution was stirred at room temperature for $24 \mathrm{~h}$, then $1 \mathrm{~cm}^{3} \mathrm{NaOH}(1 \mathrm{M}$ in $\mathrm{MeOH})$ was added with vigorous stirring. The reaction mixture was stirred for an additional hour at room temperature and the solvents were then evaporated. The residue was dissolved in a mixture of $10 \mathrm{~cm}^{3} \mathrm{H}_{2} \mathrm{O}$ and $1 \mathrm{~cm}^{3} 10 \% \mathrm{HCl}$ and extracted with diethyl ether $\left(3 \times 10 \mathrm{~cm}^{3}\right)$. The combined organic extracts were washed with saturated aqueous $\mathrm{NaHCO}_{3}$ solution, $\mathrm{H}_{2} \mathrm{O}$, and brine, dried over anhydrous $\mathrm{MgSO}_{4}$, and concentrated under vacuum. The product was purified by column chromatography on silica gel with hexane-EtOAc (10:1) as eluent.

Acknowledgments We are grateful to the Ministry of Science and Higher Education (Poland) for financial support (grant no. PBZ-KBNNN204 555 939).

Open Access This article is distributed under the terms of the Creative Commons Attribution License which permits any use, distribution, and reproduction in any medium, provided the original author(s) and the source are credited.

\section{References}

1. Blaser HU, Spindler F, Studer M (2001) Appl Catal A Gen 221:119

2. Ojima I (2000) Catalytic Asymmetric Synthesis. Wiley-VCH, New York

3. Bartók M (2010) Chem Rev 110:1663

4. Mallat T, Orglmeister E, Baiker A (2007) Chem Rev 107:4863

5. Bartók M (2006) Curr Org Chem 10:1533

6. Osawa T, Harada T, Takayasu O (2006) Curr Org Chem 10:1513

7. Mimoun H, de Saint Laumer JY, Giannini L, Scopelliti R, Floriani C (1999) J Am Chem Soc 121:6158

8. Marciniec B (2009) Hydrosilylation: a comprehensive review on recent advances. Springer, Berlin

9. Nishiyama H (1999) Hydrosilylation of carbonyl and imino groups. In: Jacobsen EN, Pfaltz A, Yamamoto H (eds) Comprehensive asymmetric catalysis. Springer, Berlin, p 267

10. Diez-González S, Nolan SP (2007) Org Prep Proced Int 39:523

11. Carpentier J-F, Bette V (2002) Curr Org Chem 6:913

12. Riant O, Mostefaï N, Courmarcel J (2004) Synthesis 2943

13. Hayashi T (2000) Acc Chem Res 33:354

14. Roy AK (2007) Adv Organomet Chem 55:1

15. Diez-González S, Nolan SP (2008) Acc Chem Res 41:349 
16. Brunner H, Becker R, Riepl G (1984) Organometallics 3:1354

17. Nishiyama H, Yamaguchi S, Kondo M, Itoh K (1992) J Org Chem 57:4306

18. Evans DA, Michael FE, Tedrow JS, Campos KR (2003) J Am Chem Soc 125:3534

19. Gade LH, César V, Bellemin-Laponnaz S (2004) Angew Chem Int Ed 43:1014

20. Song C, Ma C, Ma Y, Feng W, Ma S, Chai Q, Andrus MB (2005) Tetrahedron Lett 46:3241

21. Shaikh NS, Enthaler S, Junge K, Beller M (2008) Angew Chem Int Ed 47:2497

22. Hosokawa S, Ito J, Nishiyama H (2010) Organometallics 29:5773

23. Yun J, Buchwald SL (1999) J Am Chem Soc 121:5640

24. Gawroński J, Kołbon H, Kwit M, Katrusiak A (2000) J Org Chem 65:5768

25. Gawroński J, Gawrońska K, Grajewski J, Kwit M, Plutecka A, Rychlewska U (2006) Chem Eur J 12:1807

26. Kuhnert N, Straßnig C, Lopez-Periago AM (2002) Tetrahedron Asymmetry 13:123

27. Gawroński J, Kwit M, Grajewski J, Gajewy J, Długokińska A (2007) Tetrahedron Asymmetry 18:2632

28. Kwit M, Skowronek P, Kołbon H, Gawroński J (2005) Chirality 17:S93

29. Kwit M, Gawroński J (2003) Tetrahedron Asymmetry 14:1303

30. Gérard S, Pressel Y, Riant O (2005) Tetrahedron Asymmetry 16:1889

31. Bandini M, Melucci M, Piccinelli F, Sinisi R, Tommasi S, Umani-Ronchi A (2007) Chem Commun 4519

32. Gajewy J, Kwit M, Gawroński J (2009) Adv Synth Catal $351: 1055$

33. Gajewy J, Gawroński J, Kwit M (2011) Org Biomol Chem 9:3863

34. Mastranzo VM, Quintero L, de Parrodi CA, Juaristi E, Walsh PJ (2004) Tetrahedron 60:1781

35. Mikami K, Matsukawa S (1997) Nature 385:613

36. Ohkuma T, Doucet H, Pham T, Mikami K, Korenaga T, Terada M, Noyori R (1998) J Am Chem Soc 120:1086

37. Costa AM, Jimeno C, Gavenonis J, Carroll PJ, Walsh PJ (2002) J Am Chem Soc 124:6929

38. Ushio H, Mikami K (2005) Tetrahedron Lett 46:2903

39. Bette V, Mortreux A, Savoia D, Carpentier J-F (2005) Adv Synth Catal 347:289

40. Bette V, Mortreux A, Lehmann CW, Carpentier J-F (2003) Chem Commun 332

41. Meyer N, Roesky PW (2007) Z Anorg Allg Chem 633:2292

42. Kwit M, Gawroński J (2003) Tetrahedron 59:9323

43. Savoia D, Gualandi A, Stoeckli-Evans H (2010) Org Biomol Chem 8:3992

44. Gualandi A, Grilli S, Savoia D, Kwit M, Gawroński J (2011) Org Biomol Chem 9:3863

45. Robb MA, Cheeseman JR, Montgomery JA, Vreven T Jr, Kudin KN, Burant JC, Millam JM, Iyengar SS, Tomasi J, Barone V, Mennucci B, Cossi M, Scalmani G, Rega N, Petersson GA, Nakatsuji H, Hada M, Ehara M, Toyota K, Fukuda R, Hasegawa J, Ishida M, Nakajima T, Honda Y, Kitao O, Nakai H, Klene M, Li X, Knox JE, Hratchian HP, Cross JB, Bakken V, Adamo C, Jaramillo J, Gomperts R, Stratmann RE, Yazyev O, Austin AJ,
Cammi R, Pomelli C, Ochterski JW, Ayala PY, Morokuma K, Voth GA, Salvador P, Dannenberg JJ, Zakrzewski VG, Dapprich S, Daniels AD, Strain MC, Farkas O, Malick DK, Rabuck AD, Raghavachari K, Foresman JB, Ortiz JV, Cui Q, Baboul AG, Clifford S, Cioslowski J, Stefanov BB, Liu G, Liashenko A, Piskorz P, Komaromi I, Martin RL, Fox DJ, Keith T, Al-Laham MA, Peng CY, Nanayakkara A, Challacombe M, Gill PMW, Johnson B, Chen W, Wong MW, Gonzalez C, Pople JA (2004) Gaussian 03 (Revision D.0), Gaussian Inc, Wallingford

46. Gajewy J, Gawroński J, Kwit M (2012) Organometallics (submitted)

47. Morris DJ, Hayes AM, Wills M (2006) J Org Chem 71:7035

48. Utsukihara T, Misumi O, Kato N, Kuroiwa T, Horiuchi CA (2006) Tetrahedron Asymmetry 17:1179

49. Le Roux E, Malacea R, Manoury E, Poli R, Gonsalvi L, Peruzzinia M (2007) Adv Synth Catal 349:309

50. Biswas K, Prieto O, Goldsmith PJ, Woodward S (2005) Angew Chem Int Ed 44:2232

51. Shimizu H, Igarashi D, Kuriyama W, Yusa Y, Sayo N, Saito T (2007) Org Lett 9:1655

52. Singh RP, Twamley B, Fabry-Asztalos L, Matteson DS, Shreeve JM (2000) J Org Chem 65:8123

53. Yong KH, Chong JM (2002) Org Lett 4:4139

54. Xu Q, Zhou H, Geng X, Chen P (2009) Tetrahedron 65:2232

55. Dearden MJ, Firkin CR, Hermet J-PR, O'Brien P (2002) J Am Chem Soc 124:11870

56. Homann MJ, Vail RB, Previte E, Tamarez M, Morgan B, Dodds DR, Zaks A (2004) Tetrahedron 60:789

57. Stampfer W, Kosjek B, Faber K, Kroutil W (2003) J Org Chem $68: 402$

58. Wu X, Liu X, Zhao G (2005) Tetrahedron Asymmetry 16:2299

59. Duan HF, Xie J-H, Shi W-J, Zhang Q, Zhou Q-L (2006) Org Lett $8: 1479$

60. Stanchev S, Rakovska R, Berova N, Snatzke G (1995) Tetrahedron Asymmetry 6:183

61. Ohkuma T, Koizumi M, Yoshida M, Noyori R (2000) Org Lett 2:1749

62. Salvi NA, Chattopadhyay S (2001) Tetrahedron 57:2833

63. Lee EK, Kim SH, Jung BH, Ahn WS, Kim GJ (2003) Tetrahedron Lett 44:1971

64. Etxebarria J, Degenbeck H, Felten AS, Serres S, Nieto N, VidalFerran A (2009) J Org Chem 74:8794

65. Kylmälä T, Kuuloja N, Xu Y, Rissanen K, Franzén R (2008) Eur J Org Chem 4019

66. Sun J, Zhu C, Dai Z, Yang M, Pan Y, Hu H (2004) J Org Chem 69:8500

67. Gao JX, Yi XD, Xu PP, Tang CL, Wan HL, Ikariya T (1999) J Organomet Chem 592:290

68. Zhang G, Yashima E, Woggon WD (2009) Adv Synth Catal 351:1255

69. Aoyama H, Tokunaga M, Kiyosu J, Iwasawa T, Obora Y, Tsuji Y (2005) J Am Chem Soc 127:10474

70. Yeori A, Goldberg I, Shuster M, Kol M (2006) J Am Chem Soc 128:13062

71. Hesemann P, Moreau JJE, Soto T (2003) Synth Commun 33:183

72. Sarnicka A, Starynowicz P, Lisowski J (2012) Chem Commun 48:2237 